\title{
Encephalitis lethargica: Last century's long haulers?
}

Cite as: CMAJ 2021 September 20;193:E1468-70. doi: 10.1503/cmaj.210807

linicians began describing chronic postviral conditions such as "post-influenzal hysteria" as early as the 1890 s. $^{1}$ But their accounts were often vague and plagued by questionable generalizations. It was the massive expansion of public health systems around the time of the 1918 flu pandemic that ultimately helped bring the chronic sequelae of viral diseases to light. When Constantin von Economo (an Austrian neuroanatomist) described a handful of acute cases of Encephalitis lethargica in 1917, he highlighted symptoms of fever, headache, ocular paralysis and extraordinary sleepiness. Many saw the syndrome as related to the same virus that caused the 1918 flu pandemic, but causality was never confirmed or rejected. ${ }^{2}$ This uncertainty intensified efforts to understand chronic forms of encephalitis, even as the flu pandemic receded during the 1920s. ${ }^{3}$

Investigators in America convened consensus conferences and massive bibliographic research projects to understand encephalitis, culminating in a 1929 report that compiled the results of more than 4000 publications documenting roughly 50000 acute cases worldwide. ${ }^{4}$ They also developed an extreme slow-motion cinematography to study the parkinsonian tremors of those with chronic encephalitis. ${ }^{5}$ Leading clinicians in France criticized public health surveillance for failing to identify the tens of thousands of acute cases of encephalitis that they suspected lurked within the general population. ${ }^{6}$ A handful of neuropsychiatrists in Germany conducted extensive interviews with their patients with chronic encephalitis while hoping to gain insight into related conditions such as catatonic schizophrenia. ${ }^{7}$
Britain's cutting-edge public health system generated both a high number of officially recorded cases of "epidemic encephalitis," and widespread public

concerns about its chronic effects. The shift in nomenclature reflected the growing fear that Encephalitis lethargica was both an inchoate collection of symptoms

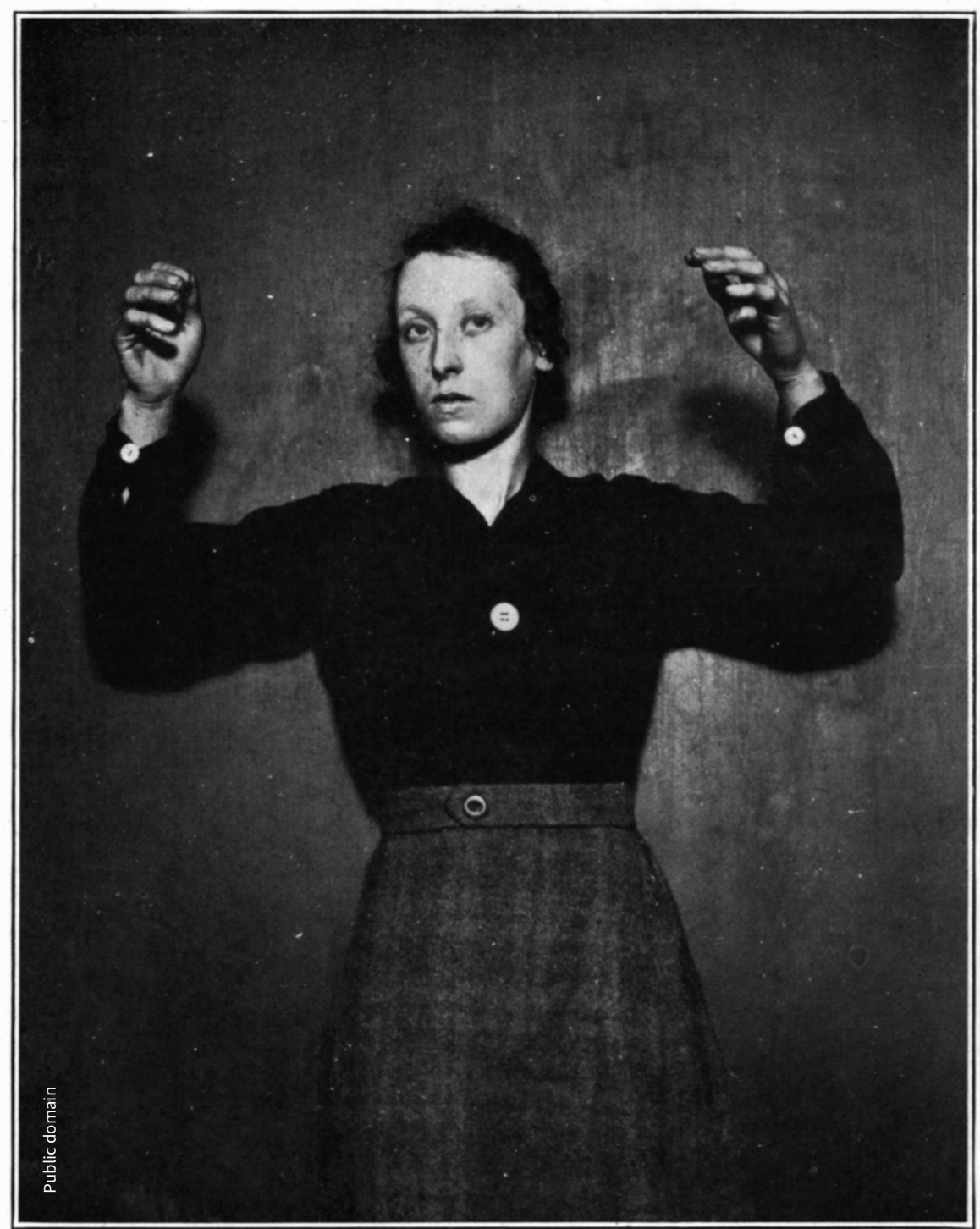

Figure 1: A photograph (Plate XV) from A.J. Hall's Epidemic encephalitis (1924). Such images reinforced Hall's early approach to patients' postencephalitis as characterized by diminished emotional tone (the "expressionless face") and impaired willpower (Hall noted that, without any instruction, the patient did not resist having her arms moved to this position and made no effort to return them to a normal posture after the photograph was taken). 
and a true epidemic. Despite extensive public health surveillance, British authorities routinely claimed that most cases likely went unreported and that encephalitis' long-term sequelae - including chronic fatigue, insomnia, tremors, gait and ocular disturbances, and radical behavioural changes that contributed to juvenile delinquency - could emerge from mild acute cases.

Based out of Sheffield, an industrial centre of about half a million people, Arthur J. Hall emerged as the foremost British authority on the disease and its importance. Hall (1866-1951) enjoyed a national reputation as a brilliant educator and adept administrator who had singlehandedly modernized his hometown's medical faculty. He became interested in the clusters of cases of encephalitis that began to appear in Sheffield in early 1924, and his encephalitis clinic at the Sheffield Royal Hospital took in hundreds of cases in just a few months. By the end of the year, Hall had amassed sufficient observations to produce an influential and richly illustrated monograph, complete with a pull-out poster, detailing the diverse and complex nature of symptoms of encephalitis to better guide the country's general practitioners in identifying and reporting the condition, which Hall, like so many others, insisted was widespread yet invisible to public health surveillance. $^{8}$

Hall's dedication to following the trajectory of his patients with encephalitis beyond the 1924 publication of Epidemic encephalitis is testament to how empathetic clinical observation emerged alongside the changes in British medical policy and provision. The effects of expanding health insurance coverage for workers and more extensive psychological supports for schoolchildren and parents rippled through British society during the 1920s. Historians have shown how these developments transformed primary medical care to include more attention to the patient's psyche and emotions. ${ }^{9,10}$ Hall's engagement with his patients changed similarly. Patients' voices were entirely absent in his 1924 monograph, for example. Photographic images of patients in various stages of catatonic paralysis further emphasized

\section{The more he studied postencephalitis, the more importance Hall placed on patient testimony.}

their helplessness and lack of agency (Figure 1). Hall's attention to his patients intensified throughout the 1920 s and 1930s even as outbreaks of encephalitis receded. His casebooks at the University of Sheffield Archives show his efforts to document the all-encompassing changes experienced by his "PEPs" (postencephalitic patients), to the extent that he covertly observed them struggling to control their tremors well enough to light a cigarette after a bicycle ride, or to feed themselves soup at the Sheffield medical club that Hall himself had founded years earlier.

Tremors and rigidity were not the only postencephalitic symptoms that piqued Hall's curiosity. His clinical notes show how he followed his patients' fates over decades doggedly, using newspaper reports, obituaries and family interviews to try to determine whether and to what extent sequelae of encephalitis might have led to their death - by accident or suicide. Although Hall found both untimely ends to be improbably frequent, his approach was less statistically inspired than it was impassioned by his desire to accurately categorize postencephalitic disabilities to better manage patients' long-term care.

The more he studied postencephalitis, the more importance Hall placed on patient testimony. Hall's archives contain multiple meticulously documented accounts from patients about their conditions, which shows his ongoing engagement with such evidence. Tincture of belladonna was a common treatment for patients with postencephalitis who had parkinsonian symptoms, and it paradoxically appeared to be more effective than more powerful extracts like atropine or scopolamine. Hall's explanation for this phenomenon came directly from his patients' accounts, in which they described a euphoric feeling of release that enabled them to move with less thought and effort, encouraging them to move more and thereby intensifying belladonna's mild initial psychological effects. Hall also relied on patients' self-reported psychological and emotional states to guide the administration of atropine: he concluded that if a patient's psychological capacity was severely compromised, the use of atropine was not indicated.

Encephalitis was often described as an utterly mysterious affliction that appeared seemingly at random and that slowly and insidiously robbed its victims of any hope for the future. Hall's increased attention to his patients' expressions of their plight might seem like a straightforwardly empathetic response to a profound human tragedy. Historical research, however, helps us understand his efforts in the context of his time and place. Hall's local and national reputation empowered him to create a system that collected and amplified patient voices. He saw little distinction between making Britain's new systems empathetic and making them efficient. More than ever before, these systems were designed to care for Britons throughout their lives. Private insurance, of course, had long been in place, and the impetus for Hall's compassionate interests in long-term observations of PEPs came not only from his engagement with public institutions but also from his routine work involving patients for private insurance coverage - a common practice among British doctors of the era, ${ }^{11}$ and one that further encouraged Hall to imagine his patients' conditions as evolving over the long term.

Patients with encephalitis directly benefited from Hall's clinical curiosity, despite the latter's diverse sources that 
reached beyond mere empathy to the complex web of scientific, cultural and political forces facing interwar Britain. It may be advisable to devise similar ways to encourage the impassioned curiosity of those practitioners watching and caring for COVID-19 "long-haulers," as health systems are reshaped to respond to long-term challenges with greater sensitivity, responsivity and efficacy.

\section{Kenton Kroker PhD}

Program in Health \& Society, Department of Social Science, Faculty of Liberal Arts and Professional Studies, York University, Toronto, Ont.

\section{References}

1. Honigsbaum M, Krishnan L. Taking pandemic sequelae seriously: from the Russian influenza to COVID-19 long-haulers. Lancet 2020;396: 1389-91.

2. Vilensky JA, editor. Encephalitis lethargica: during and after the epidemic. New York: Oxford University Press; 2011.

3. Kroker K. Configuring epidemic encephalitis as a national and international neurological concern: technique, technology, therapy. In: The history of the brain and mind sciences. Casper ST, Gavrus D, editors. Rochester (NY): University of Rochester Press; 2017:77-106.

4. Epidemic encephalitis : etiology, epidemiology, treatment. Report of a survey by the Matheson Commission. New York: Columbia University Press; 1929.

5. Kroker K. Creatures of reason? Picturing viruses at the Pasteur Institute during the 1920s. In: Crafting immunity: working histories of clinical immunology. Kroker K, Keelan J, Mazumdar PMH, editors. Aldershot (UK): Ashgate Publishers; 2008:145-63.

6. Bernard L, Renault J. L'enquête epidémiologique du ministre de l'Hygiène sur l'encéphalite léthargique en France. Bull Acad Méd (Paris) III Ser 1920; 83:470-4.

7. Foley PJ. The Encephalitis lethargica patient as a window on the soul. In: The neurological patient in history. Jacyna LS, Casper ST, editors. Rochester (NY): University of Rochester Press; 2012:184-211.

8. Hall AJ. Epidemic encephalitis (Encephalitis lethargica). Bristol (UK): John Wright \& Sons; 1924.

9. Thomson M. Psychological subjects: identity, culture, and health in twentieth-century Britain. Oxford (UK): Oxford University Press; 2006.

10. Hayward R. The transformation of the psyche in British primary care, 1870-1970. London (UK): Bloomsbury; 2014.

11. Dupree MW. Other than healing: medical practitioners and the business of life assurance during the nineteenth and early twentieth centuries. Soc Hist Med 1997;10:79-103.

This article was solicited and has been peer reviewed.

Competing interests: Kenton Kroker has received a research grant from the Social Sciences and Humanities Research Council of Canada. No other competing interests were declared.

Content licence: This is an Open Access article distributed in accordance with the terms of the Creative Commons Attribution (CC BY-NC-ND 4.0) licence, which permits use, distribution and reproduction in any medium, provided that the original publication is properly cited, the use is noncommercial (i.e., research or educational use), and no modifications or adaptations are made. See: https://creativecommons.org/ licenses/by-nc-nd/4.0/ 